\title{
Teaching Video NeuroImage: Unique Ipsilateral Manual Automatism in Temporal Lobe Epilepsy
}

\section{Conducting the Orchestra}

Alaa S. Mohamed, MD, MSc, Christian C. Prusinski, DO, Anthony L. Ritaccio, MD, William O. Tatum, DO, and Anteneh M. Feyissa, MD, MSc

Neurology ${ }^{\circledR}$ 2021;97:e867-e868. doi:10.1212/WNL.0000000000012136

Two women aged 21 and 19 years presented with lesional drug-resistant temporal lobe epilepsy (TLE) (table) with focal impaired awareness seizures (FIAs) (figure). Inpatient video EEG monitoring captured habitual FIAs accompanied by predominant ipsilateral upper extremity automatisms that mimicked a conductor leading an orchestra (video).

Although the origins and mechanisms behind nonmanipulative unilateral upper extremity automatism are controversial, they are considered a reliable sign with localizing value in mesial

Table Clinical Characteristics of 2 Patients With Lesional Temporal Lobe Seizures Associated With Predominant Ipsilateral Upper Extremity Automatisms

\begin{tabular}{lll}
\hline & Patient 1 & Patient 2 \\
\hline Hand dominance & Right & Left \\
\hline Age ay onset, $\mathbf{y}$ & 16 & 7 \\
\hline $\begin{array}{l}\text { Habitual seizure } \\
\text { semiology }\end{array}$ & $\begin{array}{l}\text { Anxious and confused but remains verbal, } \\
\text { accompanied by floppy movements involving } \\
\text { the right upper extremity }\end{array}$ & $\begin{array}{l}\text { Unresponsive staring associated with repetitive } \\
\text { swallowing, lip-smacking, and left upper } \\
\text { extremity fumbling movements }\end{array}$ \\
\hline Seizure episode & $\begin{array}{l}\text { She grabbed her nose with her right hand, tapped } \\
\text { her head, and then started to wave her index } \\
\text { finger as if she was conducting an orchestra; later, } \\
\text { a subtle contralateral left upper extremity } \\
\text { dystonic posturing was seen }\end{array}$ & $\begin{array}{l}\text { She started to point with her left index finger, } \\
\text { wastively moved her left arm as if she }\end{array}$ \\
\hline wuting an orchestra
\end{tabular}

Abbreviations: SISCOM = subtraction ictal-interictal SPECT coregistered with MRI.
Correspondence

Dr. Feyissa

feyissa.anteneh@mayo.edu

MORE ONLINE

- Video

Teaching slides

links.lww.com/WNL/

B403 


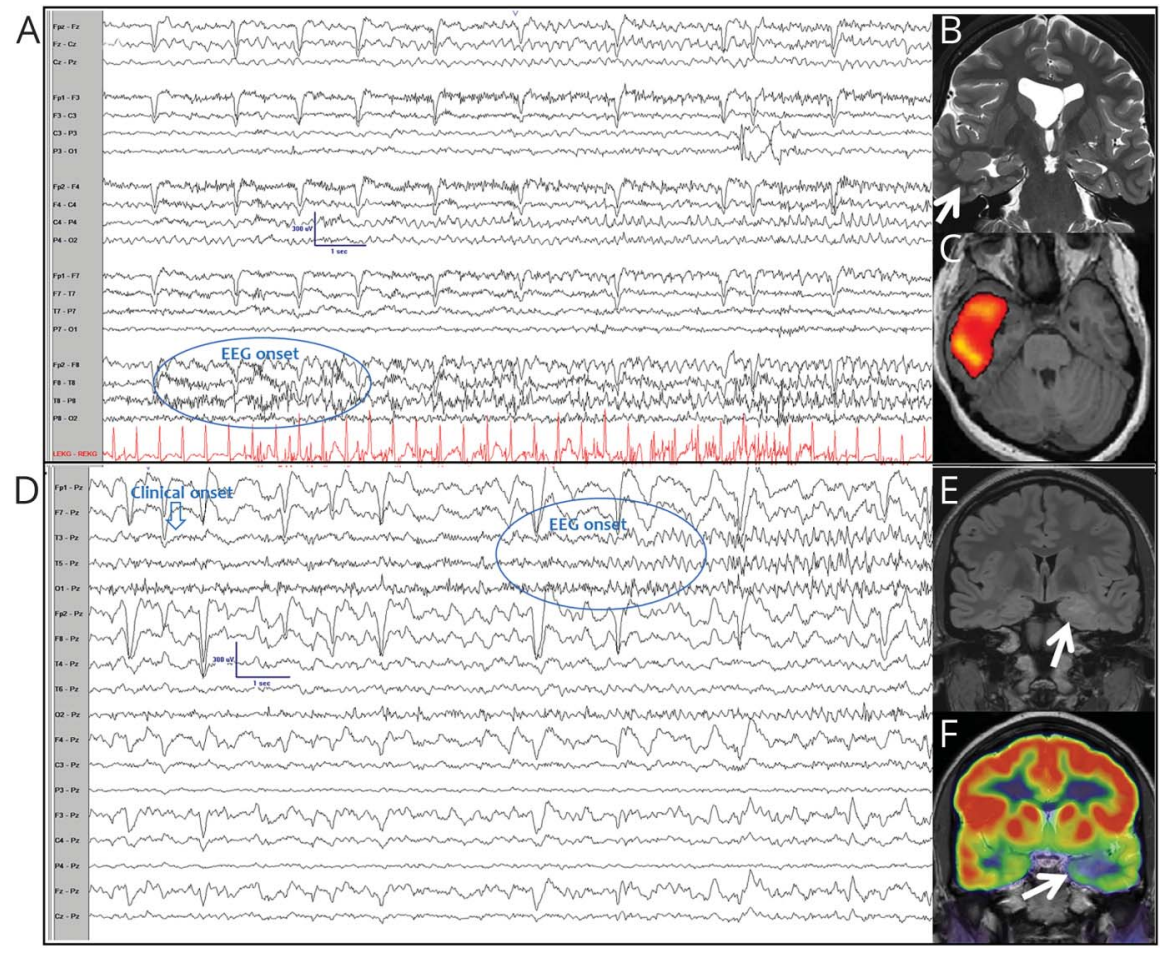

(A) A 21-year-old woman with right temporalonset seizures (clinical onset preceded EEG onset [not shown]). (B) T2-weighted MRI shows right-temporal cortical malformation. (C) SISCOM (subtraction ictal-interictal SPECT coregistered with MRI) shows right-temporal hyperperfusion. (D) A 19-year-old woman with left temporal-onset seizure. (E) Axial fluid-attenuated inversion recovery MRI shows left amygdala enlargement and hyperintensity. (F) PET scan shows left-temporal hypometabolism. EEGs in bipolar (A) and referential montage (D) displayed at $10 \mu \mathrm{V} / \mathrm{mm}, \mathrm{LFF}=1 \mathrm{~Hz}$, $\mathrm{HFF}=30 \mathrm{~Hz}$, timebase $=30 \mathrm{~mm} / \mathrm{s}$.

TLE. ${ }^{1,2}$ This is particularly true in the setting of concordant electroclinical data. When unilateral upper extremity automatisms occur with contralateral dystonia, their lateralizing value to the ipsilateral hemisphere is high. ${ }^{2}$ Our observation adds to the spectrum of manual automatisms associated with TLE.

\section{Study Funding}

No targeted funding reported.

\section{Disclosure}

The authors report no disclosures relevant to the manuscript. Go to Neurology.org/N for full disclosures.

\section{Appendix Authors}

\begin{tabular}{|c|c|c|}
\hline Name & Location & Contribution \\
\hline $\begin{array}{l}\text { Alaa S. } \\
\text { Mohamed, } \\
\text { MD, MSc }\end{array}$ & $\begin{array}{l}\text { Department of } \\
\text { Neurology, Mayo Clinic, } \\
\text { Jacksonville, FL }\end{array}$ & $\begin{array}{l}\text { Drafting and revision of the } \\
\text { manuscript for intellectual } \\
\text { content, acquisition of data, } \\
\text { editing video }\end{array}$ \\
\hline
\end{tabular}

Appendix (continued)

\begin{tabular}{lll}
\hline Name & Location & Contribution \\
\hline $\begin{array}{l}\text { Christian C. } \\
\text { Prusinski, } \\
\text { DO }\end{array}$ & $\begin{array}{l}\text { Department of } \\
\text { Neurology, Mayo Clinic, } \\
\text { Jacksonville, FL }\end{array}$ & $\begin{array}{l}\text { Drafting and revision of } \\
\text { the manuscript for intellectual } \\
\text { content, acquisition of data }\end{array}$ \\
\hline $\begin{array}{l}\text { Anthony L. } \\
\text { Ritaccio, MD }\end{array}$ & $\begin{array}{l}\text { Department of } \\
\text { Neurology, Mayo Clinic, } \\
\text { Jacksonville, FL }\end{array}$ & $\begin{array}{l}\text { Revised the manuscript for } \\
\text { intellectual content }\end{array}$ \\
\hline $\begin{array}{l}\text { William O. } \\
\text { Tatum, DO }\end{array}$ & $\begin{array}{l}\text { Department of } \\
\text { Neurology, Mayo Clinic, }\end{array}$ & $\begin{array}{l}\text { Revised the manuscript for } \\
\text { intellectual content }\end{array}$ \\
\hline $\begin{array}{l}\text { Jacksonville, FL } \\
\text { Feyissa, MD, } \\
\text { MSc }\end{array}$ & $\begin{array}{l}\text { Department of } \\
\text { Neurology, Mayo Clinic, } \\
\text { Jacksonville, FL }\end{array}$ & $\begin{array}{l}\text { Designed and conceptualized } \\
\text { study, drafting and revision } \\
\text { of the manuscript for intellectual } \\
\text { content, acquisition of data }\end{array}$ \\
& &
\end{tabular}

\section{References}

1. Mirzadjanova Z, Peters AS, Rémi J, Bilgin C, Silva Cunha JP, Noachtar S. Significance of lateralization of upper limb automatisms in temporal lobe epilepsy: a quantitative movement analysis. Epilepsia. 2010;51(10):2140-2146.

2. Kotagal P, Lüders H, Morris HH, et al. Dystonic posturing in complex partial seizures of temporal lobe onset: a new lateralizing sign. Neurology. 1989;39(2 pt 1):196-201. 


\section{Neurology}

\section{Teaching Video NeuroImage: Unique Ipsilateral Manual Automatism in Temporal Lobe Epilepsy: Conducting the Orchestra}

Alaa S. Mohamed, Christian C. Prusinski, Anthony L. Ritaccio, et al. Neurology 2021;97;e867-e868 Published Online before print April 30, 2021

DOI 10.1212/WNL.0000000000012136

This information is current as of April 30, 2021

Updated Information \& Services

References

Subspecialty Collections

Permissions \& Licensing

Reprints including high resolution figures, can be found at: http://n.neurology.org/content/97/8/e867.full

This article cites 2 articles, 1 of which you can access for free at: http://n.neurology.org/content/97/8/e867.full\#ref-list-1

This article, along with others on similar topics, appears in the following collection(s):

Epilepsy semiology

http://n.neurology.org/cgi/collection/epilepsy_semiology

Epileptogenic zone

http://n.neurology.org/cgi/collection/epileptogenic_zone

Partial seizures

http://n.neurology.org/cgi/collection/partial_seizures

Video/ EEG use in epilepsy

http://n.neurology.org/cgi/collection/video_eeg_use_in_epilepsy

Information about reproducing this article in parts (figures,tables) or in its entirety can be found online at:

http://www.neurology.org/about/about_the_journal\#permissions

Information about ordering reprints can be found online:

http://n.neurology.org/subscribers/advertise

Neurology ${ }^{\circledR}$ is the official journal of the American Academy of Neurology. Published continuously since 1951, it is now a weekly with 48 issues per year. Copyright @ 2021 American Academy of Neurology. All rights reserved. Print ISSN: 0028-3878. Online ISSN: 1526-632X.

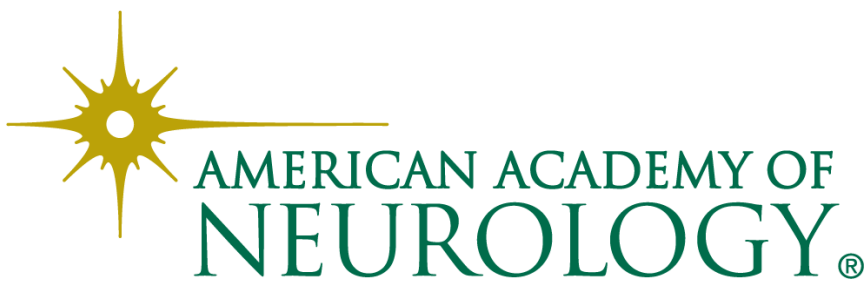

